\title{
6. "Ol Meri Bilong Wok" (Hard-working Women): Women, Work and Domesticity in Papua New Guinea
}

\author{
Jemima Mowbray \\ University of Technology Sydney
}

\section{Mi Meri Bilong Wok (I'm a hard-working woman)}

In 2007 I spent just over six months living in Basbi, a hamlet in the larger village of Hahalis on Buka Island. ${ }^{1}$ During this time I recorded oral histories and undertook fieldwork with the Halia- and Haku-speaking peoples of Buka. Their villages stretch along the north-eastern coast of Buka Island which is around 55 kilometres (34 miles) in length and at its widest 17 kilometres (10.5 miles). It is the second largest island of the Autonomous Region of Bougainville, located just to the north of the main island and separated from it by a narrow, but deep passage. Bougainville, formerly known as North Solomons, is now an autonomous region of Papua New Guinea (PNG), attaining this status after a prolonged period of secessionist conflict through the late 1980s and into the 1990s commonly referred to as "the Crisis." While the work of peace-building and reconciliation remains ongoing, the ordinary rhythms of everyday life in Bougainville had, by the early 2000s, returned. Much of my time in the village was spent with women as they worked - in their kitchens and in their gardens.

The women of Halia and Haku are hard workers; nothing stops their daily labour. Rain or shine they visit their gardens. The women may plant or harvest, they may just weed; but there is always work to be done. Invariably something will be carried back for the afternoon and evening meal. A makeshift teil or woksak (a carry basket) to transport garden foods home will be quickly woven from the leaves of nearby coconut palms, and strung to their backs with a strong, surprisingly soft cord made from the beaten bark fibre of a banana tree. Women lucky enough to own a wheelbarrow bring it along to carry their tools there and garden produce back. Once home again they must fetch water, do laundry,

1 Research for this chapter was drawn from the following archives: National Archives of Australia: A518 (A518/1), P213/3/2, Native Labour - Papua and New Guinea - Employment of Native Women; Papua New Guinea Archives: 496/ARC6A917/BN7, and Papua New Guinea Archives: 69/14-1-34/1285, Social Welfare and Advancement of Native Women Policy. 
collect firewood, prepare the lunch and evening meals. And though their unemployed (or intermittently employed) husbands might pitch in, women are also generally responsible for the care of children.

Along the east and north coast of Buka Island, limestone cliffs descend steeply to the beach. Before the 1950s, and in some areas the 1960s, villages on the east coast of Buka Island were largely found on the beach and women's gardens were planted close by, directly above the villages along the cliffs. By the 1950s the Halia and Haku were being encouraged by the colonial administration to move their villages to the top of the cliff, closer to the new path (later a karanas gravel highway) the administration was in the process of clearing. ${ }^{2}$ It was common practice across the territories for patrol officers to put pressure on villagers to relocate and reorganise the village within clearly defined, mapable boundaries. They were also often encouraged to shift or relocate the village so that it was near to a road that the local kiap (colonial patrol officer) regularly checked was being kept clean and clear. Defined residential clusters along cleared paths made the job of patrolling more convenient for government officers. ${ }^{3}$

On Buka Island by the time villages were being relocated from the beach tops to the cliff tops, the introduction of indigenous-managed cash cropping had begun in earnest. Coconut plantations had been established on land just the other side of the new road. As a result, food gardens got pushed further and further inland to their present position in the bush, ranging some 1.5 to 5 kilometres $(0.9$ to 3.1 miles) inland. This has meant a much further walk for a woman carrying her family's food and firewood back home. It has also meant a daily climb up and down the steep limestone cliffs, with women clutching multiple buckets and empty plastic bottles in order to fetch water from the main water source on the island - the kukubui (fresh water springs) along the beach.

Much has changed over the last hundred years or so, and the lives of contemporary Halia women do not very closely resemble those of their great grandmothers whose husbands were among the first to travel over to plantations in Rabaul, returning at the end of their contracts with their bokis kontrakt (labourer's case) packed with rami (a square piece of material used as clothing), an iron pot, and some beads. ${ }^{4}$ Now axes and knives, rice and noodles, school fees, imported second-hand clothes, even mobile phones, are part of everyday life. Yet many of the women I spoke with tendered to me the simple routine of daily labour, and especially their work in the garden, as evidence that not so much had changed at all.

\footnotetext{
2 Romeo Tohiana, "The Hahalis Welfare Society of Buka, North Solomons Province: its establishment, subsequent development and eventual decline, 1960-1980," Hons. thesis, Port Moresby: University of Papua New Guinea, 1982, p. 5.

3 C.D. Rowley, The New Guinea Villager, Melbourne: Cheshire, 1965, pp. 33-34; and Edward P. Wolfers, Race Relations and Colonial Rule in Papua New Guinea, Sydney: Australia and New Zealand Book Co., 1975, p. 5.

4 Tohiana, "The Hahalis Welfare Society of Buka," p. 27.
} 
When Grace, my host-mother during my stay, helped me to plant a small (token) taro garden in an allotted area of her own garden land, we used cuttings she had sourced. Grace told me it was the same taro her ancestors had planted - the same plant and indeed the very same shoot that went back into the ground. The stik taro (the stem cutting of the taro plant) was a tangible connection between Grace and her ancestors, as was our labour.

When I went with women to the gardens during my stay I was slowly introduced to a variety of small things that had to be done each time a woman visited the gardens. I was told I must periodically call out in a small wordless holler while I worked so that other women working would hear me and know I was in the gardens. I had to build a small fire before I started work so that others - nearby in their gardens, or even back in the village - would see the smoke and know I was hard at work. And as we walked back home, tired from gardening, I would be reminded to find a flower or bright leaf from the bush by the side of the path and stick it in my hair so that on arrival back in the village there would be no confusion as to where I had been. I was told these were things that had been done by Halia women since bipo tru (long ago). ${ }^{5}$ This was kastom (custom). A good Halia woman is, and always has been, industrious. These small habits help signal to others your worth, the women explained. They show everyone that you are "meri bilong wok" (a hard-working woman).

\section{Devaluing but intensifying women's work}

Buka women's significant investment and pride in being recognised as hardworking women indicates the significant value they place on their labour. This is in contrast to the way in which indigenous women's work in the Pacific has often been ignored or devalued by outside observers. Certainly during the early stages of colonialism in the Pacific, Europeans who first came into contact with indigenous women failed to read women's work for what it might tell them of women's crucial, active role within traditional cultural life. Instead women's role in subsistence, specifically the hard, physical labour this involved, was seen as the source of their "low status." In colonial Papua and New Guinea (PNG), missionary and administration attempts to "uplift the native woman," to improve her status, were aimed at transforming women's work in the village. They hoped to "lighten women's load" through a refocusing of indigenous women's labour practice around family and the home, with home envisaged as a discrete physical space marked by the boundaries of a well-kept house and garden (though not food gardens), and family as a nuclear unit comprised of

5 In this passage I have referred to Halia women. The village in which I resided during my stay was a Halia village. Though there are differences in language and custom between the two groups, my description of work in the garden and of the value women place on this work holds for the women of Haku also. 
mother, father and children. The indigenous woman would be remade as an ideal "modern" mother and wife. But despite colonial programs of reform, Papua New Guinean women today remain the primary subsistence agriculturalists in the village. In the pre-colonial gendered division of labour in most indigenous societies in Papua and New Guinea, women had been responsible for garden work, the collection of firewood and water, and the care of children. Women have continued to undertake this work, even as they have assumed responsibility for new domestic duties such as sewing, laundry, and general "housekeeping," and taken on extra work that might bring in a little cash, such as market gardening and cash cropping.

It is a clear paradox of the colonial "civilising project" in Papua and New Guinea that, even as colonial officials regarded the heavy work involved in subsistence as the source of indigenous women's low status, the administration simultaneously introduced a range of policies and programs that effectively added to and intensified women's work. This occurred as a result of colonial policies of land and labour that first excluded, and then later marginalised women from the waged labour and commodity sector; by the relocation of villages such that the distances to be travelled by women to gardens and water sources significantly increased; and even through implementation of biomedical projects of state and church that discouraged customary indigenous family-planning measures such as birth spacing, sexual abstinence (especially postpartum) and indigenous contraceptives, a factor in the significantly increasing population.

Within this paper I use a combination of methodologies, drawing on the colonial archives - government documents, correspondence and reports - in both primary and secondary sources and placing these alongside observations from fieldwork, and the life histories shared with me in interviews with women in Buka. The blending of historical and ethnographic approaches allows not only an outline of colonial intention, policy and practice, but also gives a sense of the practical and embodied consequences of these for village women. Buka women have always regarded themselves as productive, active contributors of labour, ensuring the basic subsistence of the family. And as the nature of what constituted "work" changed through the colonial period, they have actively sought to participate in this change, taking on a variety of new forms of labour including cash cropping and the marketing of garden goods, as well as seeking training and educational opportunities that might lead in the future to paid employment. Most did this as mothers - their labour undertaken to ensure the basic subsistence needs of their family were met. Setting their testimonies against the colonial archives reveals a number of important tensions and disjunctions, especially in relation to the value placed on women's work. Where outsiders and especially colonial officials have continued to devalue work done by women as "subsistence," "domestic" or "reproductive," Buka women have clearly valued both their subsistence and commodity labour as productive. 
Anne Dickson-Waiko has argued that indigenous women's exclusion from colonial society during the period of state formation, in tandem with customary gender roles meant women through the colonial period and into the present have been positioned as somehow present in and yet existing outside of the modern state. ${ }^{6}$ To the extent they have been brought within the colonial and now post-colonial state this has been,

as mothers rather than as citizens with the same rights as male citizens... while citizenship is supposedly an individual's relationship with the state, Papua New Guinean women have great difficulty in claiming rights as individual citizens. They enter the political domain as sexed beings and this construction interferes with and even sabotages their claims for equal citizenship. ${ }^{7}$

The citizen-mother, a very familiar model of female citizenship, is one rarely recognised as an equal citizen. Rather, as Carole Pateman argued in her classic though now much critiqued work on the gendering of citizenship, in traditional European understandings of the state men have been imagined as producers (in that they must work to "create" or "contract" both cultural and political relationships with one another) and are thus exemplary citizens able to exercise and access political rights. Women, on the other hand, are imagined as reproducers and as such hold subordinate status, remaining bound within the domestic or private sphere; their relationship to the state always mediated through their relationships with men (in their role as mothers and wives). ${ }^{8}$ Pateman's work recognised women's exclusion from full citizenship based on a clear division between public and private.

This is a division that has been labelled a theoretical fiction even for Europe and one that does not apply tidily (and sometimes not at all) outside of non-Western contexts. ${ }^{9}$ In PNG while there was a clear sexual division of labour prior to colonial contact, customary gender roles were understood as complementary, and certainly were not easily categorised within clearly distinguished "domestic" or "public" domains. ${ }^{10}$ Yet traditional gender relations and roles were affected by

\footnotetext{
6 Anne Dickson-Waiko, "Women, individual human rights, community rights: tensions within the Papua New Guinea state," in Women's Rights and Human Rights; International Historical Perspectives, ed. Patricia Grimshaw, Katie Holmes and Marilyn Lake, Basingstoke, Hampshire Palgrave, 2001, pp. 49-70, pp. 50-55.

7 Anne Dickson-Waiko, "The missing rib: mobilizing church women for change in Papua New Guinea, Oceania 74(1\&2) (2003): 98-119, p. 102.

8 Carole Pateman, The Sexual Contract, Cambridge: Polity, 1988.

9 For a good overview of literature assessing and critiquing the distinction, see Joan B. Landes, "Further thoughts on the public/private distinction," Journal of Women's History 15(2) (2003): 28-39.

10 Anne Dickson-Waiko, "Colonial enclaves and domestic spaces in British New Guinea," in Britishness Abroad: Transnational Movements and Imperial Cultures, ed. Kate Darian Smith, Patricia Grimshaw and Stuart Macintyre, Carlton: Melbourne University Press, 2007, pp. 205-30, p. 212; Marilyn Strathern, Gender of the Gift: Problems with Women and Problems with Society in Melanesia, Berkeley: University of California Press, 1988.
} 
colonialism, not least through the colonisers' promotion of an ideal of Victorian "separate spheres," and the imposition of the colonial (and equally the postcolonial) state and with this the emergence of new colonial "political" domains.

Dickson-Waiko has identified the emergence of colonial public and domestic domains along spatial lines in the early colonial period. ${ }^{11}$ She persuasively argued that the Papuan administration's early protectionist policies restricting women to the village while recruiting men to plantation work, and other waged work in colonial homes and the administration created a new labour hierarchy in which indigenous men's paid labour undertaken in the public colonial domain was regarded as more important than subsistence agriculture in village gardens. This led to a gendering of colonial space such that the village came to be classed as feminised domestic or "private" space. This was a racialised as well as gendered distinction between the village as a domestic space, and colonial urban townships as the public domain, with the urban/rural divide mirroring a Eurocentric public/private split and, I would add intersecting with a colonial dichotomy of modernity/tradition. ${ }^{12}$

Indigenous women's work was marked as "domestic," but this was a "domesticity" of a different nature to that envisaged within the Victorian model of separate spheres. Victorian notions of femininity were characterised by an ideal of middle-class womanhood in which the labour of women was confined to the home (defined physically and relationally) and thus rendered invisible and often characterised in terms of its moral and religious value; women were "angels in the home."13 Village women's work in the gardens was heavy physical labour, and undertaken outside of the home, and yet through the colonial classification of the village as "domestic" and as such a domain not recognised as either public or political allowed colonial agents to regard the subsistence work of indigenous women as secondary to the labour of indigenous men. Men were recognised as active economic agents, but women's work could be ignored.

In this paper I extend on Dickson-Waiko's thesis, to argue that in the post-war period work done by women in the village - in the gardens, on plantationswas undertaken in their role as mothers. It was thus devalued and ultimately dismissed by outsiders and colonial officials as domestic or reproductive, even when it was work that generated income and engaged women in market-based exchange. I further take my cue from Dickson-Waiko in her focus on the policies of the colonial state. Much has been written about the attempts of colonial missionaries to instill in Papua New Guinean women an ideal of domesticity,

11 Dickson-Waiko, "Colonial enclaves and domestic spaces in British New Guinea," p. 216.

12 Ibid., pp. 216-17.

13 Catherine Hall and Leonore Davidoff, Family Fortunes: Men and Women of the English Middle Class, 1780-1850, Chicago, Ill: University of Chicago Press, 1987. 
to introduce them to the Victorian "cult of domesticity."14 This paper, while recognising mission influence, argues that the policies and programs of the colonial state were significant, fundamental even, in reshaping the domestic life of village women.

\section{Early colonial policy regarding indigenous women}

Though always crucial within the Australian colonial project, in the early colonial period Papua New Guinean women were effectively sidelined by the colonial administration. Indigenous men were given colonial positions of authority in the villages (as luluai and tultuls in New Guinea and village constables in Papua). Men were recruited to the native constabulary and employed as indentured labourers on plantations. And men, not women, were brought into colonial homes as domestic servants (hausbois not hausmeris). ${ }^{15}$ Despite the efforts of some missions to provide for the education of girls, it was primarily men who were the beneficiaries of the very limited educational opportunities provided by the missions in the two colonies before World War II.

14 Diane Langmore, “Object lesson of a civilised, Christian home," in Family and Gender in the Pacific: Domestic Contradictions and the Colonial Impact, ed. Margaret Jolly and Martha Macintyre, Cambridge: Cambridge University Press, 1989, pp. 84-94; Diane Langmore, Missionary Lives: Papua 1874-1914, Honolulu: University of Hawai'i Press, 1989; Martha Macintyre, "Better homes and gardens," in Family and Gender in the Pacific: Domestic Contradictions and the Colonial Impact, ed. Margaret Jolly and Martha Macintyre, Cambridge: Cambridge University Press, 1989, pp. 156-69; Mary Taylor Huber and Nancy C. Lutkehaus (eds), Gendered Missions: Women and Men in Missionary Discourse and Practice, Ann Arbor: University of Michigan Press, 1999.

15 During the early period of colonial rule in the territories there were some differences in the labour legislation of Papua and New Guinea, which meant there were higher numbers of women working as domestics in New Guinea (although the overall figure was still low). However, this did not continue for long once New Guinea became a mandated territory after World War I. Restrictions were placed on the recruitment of single indigenous women and only married indigenous women were allowed to work as domestic servants under contract. Only a married European woman in possession of a special permit could employ an unmarried indigenous woman. This form of restriction continued even under the early Labour Ordinances of the post-war period. Labour restrictions on employing indigenous women were at least partly justified by the administration as an attempt to "protect" indigenous women from the unwanted attentions of European men. Many British African colonies had similar labour restrictions and as a result there was a predominantly male domestic work force, though this was not necessarily the case across all of the South Pacific. In Papua and New Guinea, and other Pacific colonies such as Vanuatu, restrictions against the employment of women as domestic servants were eased after World War II with the result that an increasing number of women were employed as hausmeris from the 1950s. See Native Labour-Papua and New Guinea-Employment of Native Women, National Archives of Australia, A518 (A518/1), P213/3/2. For the case of Vanuatu, see Margaret Rodman, Daniela Kraemer, Lissant Bolton and Jean Tarisesei (eds), House-Girls Remember: Domestic Workers in Vanuatu, Honolulu: University of Hawai'i Press, 2007. For British colonies in Africa see Karen Tranberg Hansen, "Body politics: sexuality, gender, and domestic service in Zambia," Journal of Women's History 2(1) (1990): 120-42; and Deborah Gaitskell, "Housewives, maids or mothers: some contradictions of domesticity for Christian women in Johannesburg, 1903-1939," The Journal of African History 24(2) (1983): 241-56. 
Colonial observers - early European explorers, colonial officers, planters, settlers, travellers, missionaries and anthropologists - often assumed indigenous women to be lacking responsiveness, and ill-equipped to adapt to modern ideas and change. Sir John Hubert Murray, Lieutenant Governor of Papua from 1908 to 1940, for example, expressed clear pessimism regarding women's ability to modernise when writing about the situation of women in Papua in 1923:

I do not think that much can be done for the women in the villages, as distinct from the men. In the larger villages it may be possible to give some of the women simple instruction in nursing (especially in the case of childbirth) and in the care of children, and it may also be possible to teach them some industry which they can carry on in their homes and which may bring a quick return-e.g. lacemaking; this will probably relieve them from some of their heavier tasks and may improve their position generally, but it is a method which can only be employed occasionally and under exceptional circumstances. ${ }^{16}$

The assumption of "natural female conservatism" remained a fundamental feature of colonial discourse, with indigenous women being described by female welfare officers as the "bulwarks of village conservatism" into the late 1950s. ${ }^{17}$ And this assumption meant indigenous women were consistently positioned by the colonial administration as both a brake to, and remedy for, rapid change in the village context.

The marginalisation of indigenous women from colonial society should thus not be understood as having occurred because the administration simply ignored women, but rather because it actively sought to "lock" them in the village. As the key to assuring continued village settlement, women were prohibited from entering into indentured labour contracts and discouraged from leaving the village to accompany their husbands to plantations. Murray explained the prohibition on the basis that if women were to be employed on plantations then, "the native villages might be broken up, social life decay, the men might not return."18 If women remained in the village, "the men may drift away, but they will come back." ${ }^{19}$ Early colonial administrators in Papua and New Guinea did not want to see the indigenous population turned from "a race of peasant proprietors" into "a landless proletariat, entirely dependent on plantations for

16 Sir Hubert Murray in response to a query regarding women's position in Papua from Anna Bugge-Wicksell (the sole female member of the League of Nation's Permanent Mandates), "Situation of women, 1922-23," quoted in Susan Gardner, "Sir Paul and the Sleeping Beauty, or: some reflections on women, 'development,' and administration in Hasluck's A Time for Building," Research in Melanesia (December 1976): 31-32, p. 31.

17 See for example Lois Niall, "The education of native women as an aspect of cultural assimilation," Paper presented at the Camilla Wedgwood Memorial Lecture and Seminar, Port Moresby, Papua New Guinea, 1959, p. 85.

18 J.P.H. Murray, Papua of Today, London: P.S. King and Son, 1925, p. 114.

19 Ibid., p. 114. 
their livelihood." ${ }^{20}$ While Murray and later colonial officers explained their focus on village preservation as a humane concern for indigenous welfare, Peter Fitzpatrick has convincingly argued that this was motivated primarily by colonial fears regarding migration to urban centres and the risks this posed for disruptive class organisation. ${ }^{21}$ Given the small number of Australian colonial staff and the limited resources allocated to them, the administration could not afford to see village structures break down.

Preserving "the village" also had the effect of keeping the wages of indentured labourers low. In Papua and New Guinea the wages of indentured labourersinvariably recruited from outside the local area, so migrant labourers - were reckoned on the basis that they were single men and thus designed to cover (just barely) the basic subsistence of a single male. As Azeem Amarshi and Peter Fitzpatrick have both argued, women's labour in the villages effectively subsidised the plantation, not simply through subsistence labour in gardens but also the collection of firewood and water, preparation of foods, and their caring for and raising children. ${ }^{22}$ This occurred in two ways. First the provision of homes and a subsistence base allowed capitalist plantations to pay male labourers an absolute minimum wage. Additionally women's labour in the village provided what was essentially a social security system for displaced workers and the elderly. Women bore the extra labour load men's absence implied, and often reluctantly took on work traditionally considered to be men's subsistence work (clearing land, building fences, building houses, and so on) as well as, in some instances, men's customary obligations. ${ }^{23}$

With wages for indentured labourers frozen from the turn of the century until after World War II, very little to no capital accumulation by plantation labourers

20 J.P.H. Murray, Review of the Australian Administration in Papua from 1907 to 1920, Port Moresby: Government Printer, ca. 1920, p. 32. See also James Griffin, Hank Nelson and Stewart Firth (eds), Papua New Guinea: A Political History, Richmond, Vic.: Heinemann Educational Australia, 1979, p. 26. Later officials were equally adamant. See Paul Hasluck's discussion of this as a priority of Government (Hasluck was Minister for Territories, 1951 to 1963) in Paul Hasluck, A Time for Building, Carlton, Vic.: Melbourne University Press, 1976, p. 229.

21 Peter Fitzpatrick, Law and State in Papua New Guinea, Law, State, and Society Series, London, New York: Academic Press, 1980, p. 2. See, for example, Paul Hasluck's minutes from 1956 regarding native labour policy in his memoir A Time for Building. "The special concern of the Government over the risk of building up a 'landless proleteriat' and over the congregation of 'foreign' natives on the outskirts of the larger towns, has been made clear on several occasions and action has been taken to try to reduce both risks." Hasluck, A Time for Building, p. 229.

22 Azeem Amarshi, "The plantation system," in Development and Dependency: The Political Economy of Papua New Guinea, ed. Azeem Amarshi, Kenneth Good and Rex Mortimer, Melbourne: Oxford University Press, 1979, pp. 25-45, p. 30; Fitzpatrick, Law and State in Papua New Guinea, pp. 1-27. See also Ester Boserup, Woman's Role in Economic Development, London: Allen \& Unwin, 1970; Carmen Diana Deere, "Rural women's subsistence production in the capitalist periphery," Review of Radical Political Economics 8(1) (1976): 9-17. Boserup has shown that this was also the case across Africa, where again male workers' wages were kept at a level insufficient to provide for the worker's family.

23 Jennifer J. Martins, "Women and underdevelopment in rural Papua New Guinea," Hons. thesis, Adelaide: Flinders University, 1977, pp. 33-34. 
occurred during this period. An indigenous women saw very little in return for her husband's absence: perhaps a calico rami (cloth used for clothing), an iron pot, or some beads brought back at the end of her husband's contract. Although these were desirable consumer goods and no doubt brought some prestige for the women who possessed them, their introduction effectively devalued local handicraft skills traditionally associated with women, for example calico displaced tapa cloth (paper bark cloth often with intricate design work generally made by women) and iron pots replaced clay pottery. ${ }^{24} \mathrm{~A}$ telling example of the gendered impact of introduced commodities is the loss of pot-making skillsand with this a measure of social and economic status - among Motuan women as a result of the decline of the Hiri. The Hiri was a regional trade network involving the exchange of clay pots (made and owned by women) for foodstuffs, that came to an end once Motuan men entered into waged labour and the reliance on European goods became clearly established (by around the 1930s). Pot making had provided Motuan women with a certain social and economic status, but also - and not insignificantly — creative satisfaction. When the Hiri died out Motuan women stopped making pots, leading to the loss of this skillset among village women almost within a generation..$^{25}$

\title{
Post-war "welfare and development": The indigenous man as "peasant farmer"
}

\begin{abstract}
After the Second World War those within the administration and the Australian Government believed economic development in the territories should take place through indigenous agricultural enterprise. ${ }^{26}$ Huntley Wright has described the
\end{abstract}

24 S. Bailey, "The education of women in Papua New Guinea: the development of the process of female role definition in the central district since 1873," B.A. (Honours) thesis, Armidale, University of New England, 1972, cited in Penny Palmer, Girls in High School in Papua New Guinea: Problems of the Past, Present and Future, ERU Research Report No. 23. Port Moresby: Educational Research Unit, University of Papua New Guinea, 1978, p. 17.

25 The Hiri was an important regional trading network involving the Motu-speaking peoples of Papua and the Kerema peoples of the Gulf. Before colonisation, the Hiri had been involved in an annual trade expedition in which Motuan men - in significant numbers - left their villages and undertook a long and often dangerous voyage to sail west to the Gulf in order to exchange clay pots made by Motuan women for vital supplies of sago and other foodstuffs. By the 1930s, however, the numbers of men needed to stage a Hiri expedition were no longer available because of men's entry into the waged labour market. Pot making had been a significant undertaking for women; the scale of the industry evident from estimates that each annual Hiri involved trade of somewhere between 20-30,000 clay pots (exchanged for around 150 tons of sago). Women's pot-making skills were quickly lost. Cyril Belshaw, in the 1950s, observed that only one woman in Hanuabada continued to make clay pots with any regularity. In 2007, when I did fieldwork in Hanuabada, none of the women I spoke to had ever made or knew how to make a pot. See Jemima Mowbray, "No more pots, no more tattoos: Motuan women, cultural identity, and the loss of the hiri," unpublished paper presented at Oceanic Passages: Colonialism and its Aftermath, Hobart: University of Tasmania, 23-25 June, 2010.

26 Kim Godbold, "Didiman: Australian agricultural extension officers in the Territory of Papua and New Guinea, 1945-1975," Ph.D. thesis, Queensland: University of Technology, 2010, pp. 49-81. See also Ian Downs, The Australian Trusteeship, Papua New Guinea 1945-75, Canberra: Australian Government Publishing Service, 1980, p. 31. 
general reform of Australia's colonial policy in the immediate post-war periodAdministrator J.K. Murray and Labor Minister for External Territories Eddie Wards announced a "new deal" — and more specifically the administration's efforts at promoting the "peasant farmer," as a reconciling of Australia's strategic interests in colonial development with the administration's stated concern for indigenous welfare. ${ }^{27}$ Local Government Councils introduced in 1949 were intended, argued Wright, primarily as tools of area administration able to exert "close and continuous control" over local production. The councils provided the administration with a local institution through which they could oversee local economic activity and encourage an increase in the intensity of indigenous labour. The administration's management of labour and land via councils would work in tandem with village co-operatives and a new program of agricultural extension to transform a largely subsistence economy into a commercial one. ${ }^{28}$ Agricultural extension officers (or didimen) oversaw the program run by the Department of Agriculture, Stock and Fisheries (DASF). Providing training in "scientific agricultural methods," they aimed to encourage and extend villagebased cash cropping so that village plantations might be run commercially. It was assumed indigenous men would provide the labour in the drive towards the colonies' economic development.

The administration was clear on the importance of separating out subsistence agriculture from commercial agriculture: you could not simply graft cash cropping onto existing subsistence practice. It was only through creating a "new sphere" of production that indigenous farmers would accept and implement the ideas and advice of extension officers. ${ }^{29}$ Their plan for indigenous development relied then on a gendered division of labour in which indigenous men managed village plantations and the production of economic commodities, and indigenous women would continue to provide the labour for basic subsistence for the household.

When indentured labour contracts were abolished after the war and the administration framed policy around the necessity of strengthening and

27 Huntley Wright, "Economic or political development: the evolution of 'native' local government policy in the Territory of Papua and New Guinea, 1945-1963," Australian Journal of Politics and History 48(2) (2002):193-209. And see Downs, The Australian Trusteeship, p. 31.

28 This was, Wright argues, in accordance with an agrarian doctrine of development. Wright described an agrarian doctrine of development as entailing "plans for strengthening that attachment [to customary landholdings] whilst changing the terms of occupancy." This involved transforming subsistence agriculture to a situation of individualised small holdings and the intensified (agricultural) economic activity of the small holder primarily via cash cropping. See Wright, "Economic or political development,"pp. 200-02. See also Wright, "Protecting the national interest: the Labor Government and the reform of Australia's colonial policy, 1942-1945," Journal of Labor History 82 (2002): 65-80, pp. 74-76. For a general description of plans for the transformation of a subsistence economy to an agricultural commercial one, see Diana Howlett, Papua New Guinea: Geography and Change, revised, expanded, metricated ed., Melbourne: Thomas Nelson Australia, 1973, p. 1.

29 Wright, "Economic or political development," p. 201. 
developing indigenous agricultural production, this was done on the understanding that it was utopian to think peasant subsistence could provide anything but a primitive standard of living. David Fenbury, described by Wright as the architect of the new local government policy and a key driver of post-war welfare and development policy, was clear on this point, "The ideal of the sturdy peasant proprietor, farming his piece of tribal land...is a rosy dream incapable of being realized." ${ }^{30}$

Wright described the administration's end goal as being the individualisation of smallholdings geared towards eventual commercial production. ${ }^{31}$ While indigenous men were being trained to cultivate commercial cash crops, it was expected that women would again continue to provide a subsistence base for families that would subsidise this stage of economic development. The administration hoped that concerted attention towards promoting "economic advance" would help eventually to free women from subsistence work. Money obtained from cash cropping, or men's involvement in waged labour, could be used to purchase introduced food and to construct permanent housing. The newly established Local Councils were also expected to play their part, helping to build water supply facilities and other infrastructure in the villages. ${ }^{32}$ This was the long-range plan for women. Through indigenous economic development women's subsistence burden would eventually be eased, allowing her to re-focus her energies on her (nuclear) family and the home. ${ }^{33}$

This raises the continuing inconsistency, or paradox, of colonial policy and practice: while the development priorities of the administration and those of colonial capitalism consistently required women to shoulder the greater part of subsistence labour in the territories, they nonetheless regarded women's labour as a problem, if not the problem, to be addressed in order to raise indigenous women's status. ${ }^{34}$ When the administration decided after World War II to directly

30 David Fenbury, "It could happen in New Guinea," South Pacific 1(10) (1947): 5. As Wright explains, Fenbury here was drawing the distinction between a peasant subsistence farmer and a peasant "farmer" developing his capacity for agricultural commercial production so that he might eventually develop land holdings as plantations that would enable a profitable trade in agricultural commodities. See Wright, "Economic or political development," p. 197.

31 Wright, "Economic or political development," p. 201.

32 Water tanks were a priority for Councils in the early period of their introduction. The administration felt that a successful supply of water tanks to villages in Buka would act as "a tangible sign" for villagers of what a Council could accomplish. Bougainville District Annual Report, Bougainville District 1961/62, p. 16, Papua New Guinea Archives: 496/ARC6A917/BN7.

33 See for example the Australian Commission on Higher Education in Papua and New Guinea; and George Currie, Report of the Commission on Higher Education in Papua and New Guinea, Canberra: The Commission, 1964, p. 98. Currie in his report cited The Ashby Report (a document similar to Currie's own report produced for colonial Nigeria in 1959) which explained the need for greater domestic science training on the basis that as (male) farmers became more "scientific" in their approach to the land, the ensuing development would allow and require women to become "more scientific in their approach to their homes and children." George Currie, Report of the Commission on Higher Education in Papua and New Guinea, p. 98.

34 See for example comments from the Administrator Captain Barton regarding women's situation in the British New Guinea Annual Report of 1903: “Until the male natives take a larger share of the work in the 
provide welfare for indigenous women - in the form of education and health services - this engagement was premised on both a recognition and hoped-for transformation of women's role as mother and wife. Women were to be shifted into a domestic role rather than that of agricultural producer. Thus colonial interventions were focused on regulating and managing indigenous women's behaviours and practices within the appropriately feminine, "domestic" sphere of the home and the family.

In an early essay on culture contact written between the wars, William Groves, later Director of the Department of Education, argued that a good "native education" should include efforts to "make life less arduous and less exacting for the women." ${ }^{35}$ He recommended changes to indigenous practice in the areas of housing, personal hygiene, food production and diet. Groves believed that practical reform in these areas would help "simplify their [villagers] everyday lives" and give women more time to care for their children and to "enjoy some of the refinements of life which European contact will make increasingly available." ${ }^{36}$ Colonial reforms were supposed to result in an easier life for the indigenous woman, allowing her to better meet her duties as a mother and "contribute [her] part to the general development and uplift [of the colony]."

Accordingly those involved in women's welfare work from the 1950s onwards made some efforts to encourage men to take on more of the general gardening work (related to food production). At a meeting of Women's Committee in September 1957, for example, a discussion of indigenous men's concerns about the time spent in government-initiated Women's Clubs taking time away from women's essential work in the garden led to the following recommendation in relation to future Club work: "Men should be encouraged to do the gardening instead of women and it was suggested that a competition should be held for best garden made by men with, perhaps, a flower arranging competition for the women." 38

\footnotetext{
gardens, and so relieve the women of their hard toil, an improvement of their domestic status, with well nourished and numerous children, cannot be expected," cited in Martins, "Women and underdevelopment in Rural Papua New Guinea," p. 30. For a later example see W.C. Groves, Native Education and Culture Contact in New Guinea: A Scientific Approach, Being a Study of the Part That Education Might Play in the Social Adjustment and Future Development of the Natives of the Territory of New Guinea, 1st ed. Carlton, Vic.: Melbourne University Press, [1936], reprint 1977, pp. 67-69.

35 Groves, Native Education and Culture Contact in New Guinea, p. 68.

36 Ibid., pp. 68-69.

37 Ibid.

38 Social Welfare and Advancement of Native Women Policy; Minutes of the Second Meeting of the Advisory Committee on the Education and Advancement of Women, September 13, 1957, Papua New Guinea Archives: 69/14-1-34/1285, See also Social Welfare and Advancement of Native Women; Director, Department of Education to Director, Department of Native Affairs, 3 January 1961, Papua New Guinea Archives: 69/14-1-34/1285.
} 
The general training program and suggested activities for Women's Clubs also emphasised a woman's role as homemaker, largely neglecting their role in the gardens. This aspect of women's work was acknowledged only in limited ways, for example "time in the garden" was a task fitted into the new daily chore rota that women were encouraged to draw up to maximise their efficiency. ${ }^{39}$

Additionally the extent to which women began to involve themselves in the new commodity economy emerging in the village was ignored by the colonial administration. As cash crept into the village economy women began to cultivate new crops as market goods and they took on a significant share of the work of cash cropping alongside indigenous men. Training in commercial agricultural practice delivered by colonial didimen was, however, targeted almost exclusively at men. When formal agricultural training was offered to indigenous students in 1952 no women were taken on as recruits, and they were excluded from the program up until the early $1970 s .{ }^{40}$ Nahau Rooney described what standard agricultural training in the village looked like in 1975:

When the agricultural officer comes to the village he calls a meeting of all men and explains to them a new agricultural technique, cash crop, use of fertilizers, etc. When it comes to implementation, the women are the ones who get their hands dirty; they are the ones who dig, plant and harvest. Yet they are excluded from discussions. ${ }^{41}$

Where agricultural training for women was provided it was generally limited to basic garden maintenance, and suggestions regarding the introduction of new crops for family consumption rather than the skilling up of women to be active participants within a commercial agricultural economy.

What did this shift from a largely subsistence economy to one based on commodity production mean for women in the village? How did the assertion of men's primacy as commodity producers, alongside women's marginalisation from agricultural training affect women's participation in work that brought in cash, and their claims to money made through commodity production? In the

39 Lois Niall et al., Things to Do in Women's Clubs. [Books 1-4. First 3 Months - Fourth 3 Months], Port Moresby: Dept. of Native Affairs, and South Pacific Commission Literature Bureau, 1962.

40 The first Agricultural Training College was established by the administration in 1952 at Mageri Agricultural Station, just outside of Port Moresby. Mrs Dessie Wirua was the first didimeri (indigenous female extension officer) in the territories. She commenced training in 1962 at Taliligap Extension Centre in East New Britain, and was one of the first women to attend the Rural Development Assistant's Course in Tagak, near Kavieng in 1973. See Cecilie Benjamin, "Pioneer didimeri - Mrs Dessie Wirua," Harvest 3(3) (1976): 129-31. The first large-scale intake of female students was in 1975 when thirty young women were enrolled at Vudal Agricultural College for the first time. See Susanne Bonnell, "Women at Vudal Agricultural College," Administration for Development 5 (Oct. 1975): 26-31.

41 Nahau Rooney, "What's a fair go for women?" in The Pacific Way: Social Issues in National Development, ed. Sione Tupouniua, Ron Crocombe and Claire Slatter, Suva, Fiji: South Pacific Social Sciences Association, 1975, pp. 119-21, p. 119. And see Marie Reay, "Politics, development and women in the Rural Highlands," Administration for Development 5 (1975): 4-15, p. 11. 
next section, I look at one case study on the practical consequences of these colonial initiatives and their reshaping of the "domestic," by examining the changes that have taken place in the everyday lives of Halia and Haku women on Buka Island.

\title{
The case of Buka Island: Buka women's role in subsistence work
}

\begin{abstract}
Artist Elizabeth Durack observed in the 1970s that Papua New Guinean women continued "loyally, stubbornly even" to take on the majority of subsistence work. ${ }^{42}$ Though colonial observers regularly noted women's continuing responsibility for the gardens in an ambivalent tone, like Durack, Papua New Guinean women, and Buka women as earlier noted, have generally asserted a great deal of pride about their continuing role in the gardens, and their agricultural skills. These are skills that have been passed on from mother to daughter over generations involving not only specific practical skills but also often special cultural knowledge or "garden magic." 43 Gardening was something women commonly did together, and the garden was designated, if only informally, as women's space: a space away from the eyes of men. Here women gossiped and exchanged news as they laboured.
\end{abstract}

When I was staying in Hahalis I noticed many village women would playfully tease one another by pointing out a woman's plots as being in need of weeding, describing them as "ol gaten bilong wokmeri" (the gardens of a working woman/ career woman). There was some shame attached to buying garden foods at the market, as though this was an admission your gardens were not growing well. ${ }^{44}$ But while Buka women evince a great deal of pride in their gardens and in their role in subsistence, they also recognise they are trapped by it; it is a burden. ${ }^{45}$ The substantial amount of time and energy involved in garden work leaves them little time for other activities.

The changes that have occurred in the village as a result of colonialism have not lightened women's load. Colonial officers acknowledged even at the time that change as a result of colonialism had, in fact, increased women's work. Tools introduced through contact had decreased men's workloads, but there had

\footnotetext{
42 Elizabeth Durack, Face Value; Women in Papua and New Guinea, Sydney: Ure Smith, 1970, p. 18.

43 For example Halia women, in the past, had dusted a ground root and leaf mixture onto stems of taro before planting to ensure successful propagation.

44 On a number of occasions my host mother admonished me for bringing home greens from the market because people would think her gardens couldn't provide enough foods for us.

45 This is an observation drawn from comments made to me during fieldwork and in interviews, but see also Eleanor Rimoldi, "Relationships of love and power in the Hahalis Welfare Society of Buka," Ph.D. thesis, Auckland: University of Auckland, 1982, pp. 294-300.
} 
been no comparable reduction for women. Indeed on top of their subsistence work (planting, tending, and harvesting gardens) there were now additional expectations placed on women. The situation was described in the 1964-65 Annual Report for the Bougainville district, "The men [now] also have tended to want larger, cleaner houses, more clothes for all the family, and more sophisticated foods. In addition, women are required to work alongside their men in planting and harvesting cash crops." ${ }^{\prime 6}$

On top of new additional chores, even women's labour involved in traditional subsistence had increased. Women travelled considerably further to their gardens, as these were pushed further and further inland to accommodate cash crop plantings. The additional distance required by travelling to and returning from the gardens with garden produce in tow, adds to what is already significant labour. Similarly on the smaller islands surrounding Buka, an increase in population and thus an expansion of the areas needed for residential settlement has meant gardens must be made on the mainland. ${ }^{47}$ Rachel Tsen, who is from Saposa Island just south of Buka Island, explained the consequences for women:

Island life was hard, Jemima. Especially island life after, well it came to be we can't grow gardens here on the island. We had to start to paddle and go to the mainland. And so half of our energy was used then just to paddle. And then we go and work garden and by the time we'd done some the energy is gone and then we would paddle back again. So it was really hard work. ${ }^{48}$

Women's increasing access to medical treatment for themselves and their children has meant the rate of infant mortality among the Halia and Haku has dropped significantly (as it has throughout PNG). ${ }^{49}$ And though many village women today practice a mixture of customary and introduced "family planning" measures, the women I spoke to expressed concern about the general decline of traditional practices of birth spacing, post-partum abstinence and the use of bush medicine as birth control. They drew a link between the decline of these

\footnotetext{
46 Bougainville District Annual Report; Annual Report-Bougainville District 1964/65, p. 33, Papua New Guinea Archives: 496/ARC6A917/BN7.

47 Regarding the increase in population, see National Research Institute Papua New Guinea, Papua New Guinea District and Provincial Profiles, Boroko, Papua New Guinea: The National Research Institute, March 2010.

48 Rachel Tsen, recorded interview with author, Saposa Island, Autonomous Region of Bougainville, 13 March 2007.

49 William Agyei, Fertility and Family Planning in the Third World: A Case Study of Papua New Guinea, Kent, North Ryde: Croom Helm, 1988. It is important to note, however, that rates of maternal mortality have not reduced significantly, and have increased in recent decades.
} 
practices and the significant increase in population on the island, expressing anxiety about the number of children women were now having. ${ }^{50}$ Now there are too many people and not enough land, women often said to me. ${ }^{51}$

Women also complained that the land and the sea were no longer as productive as they had been when they were younger. In the past, I was told, people had followed strict customary laws about where they were allowed to fish or go hunting. "Before there were laws you had to follow - in the bush and the saltwater. In some areas you couldn't go there. It was forbidden. You couldn't swim there - don't want to scare away all fish. Chiefs would charge this man if they went and swum here. Now they don't follow laws ... you can't find fish and shellfish too. Only a little." 52

The rules about where you could hunt and fish and even swim had helped ensure sustainable practice. Many of these rules have been abandoned or were no longer as strictly observed, mainly as a result of the increasing pressures to use all available land and sea resources in the context of a growing population and at the same time villagers' growing need for cash. So at the same time that hunting and fishing - the work of men-became less efficient and less productive, forcing families to rely more heavily on women's garden work, pressures on land resulted in generally less garden land, a higher intensity use of this and smaller yields. ${ }^{53}$

50 It is interesting to note the way in which discourse justifying colonial interventions in indigenous women's fertility in the Pacific shifted through the twentieth century from the "problem of depopulation" (code for anxiety about the perceived decline in indigenous populations because of what colonial observers believed were immoral and unsanitary traditional practices) to concern for overpopulation. This is true in Papua and New Guinea, where by the late 1960s early concerns regarding depopulation had disappeared, and the administration began to focus on the need for population control and family planning (to guard against indigenous "unrestrained fertility"). See Jemima Mowbray, "Making and narrating women as modern colonial subjects in Papua New Guinea, 1945-1976," Ph.D. thesis, Sydney: University of Sydney, 2012, pp. 176-78. For a general discussion of this shift from depopulation to overpopulation in colonial debates in the Pacific see Margaret Jolly, "Infertile states: person and collectivity, region and nation in the rhetoric of Pacific population," in Borders of Being: Citizenship, Fertility, and Sexuality in Asia and the Pacific, ed. Margaret Jolly and Kalpana Ram, Ann Arbor, MI: University of Michigan Press, 2001, pp. 262-306.

51 The increase in land disputes, for example, was identified as being a direct result of overpopulation. The conjunction of a rapidly increasing population and the development of cash crop production on the island in the 1950s led to growing pressure on land and increasing tensions and conflict between individuals and clans. When I interviewed them in 2007, most women believed land disputes had not been so prevalent and certainly nowhere near as fraught when they were children. Historically patrol officers had begun to identify this in the mid-1950s. According to a district patrol report from Buka in 1954, "Land disputes have been prominent only in the last four or five years, coincident with the development of copra production and almost invariably concern land on which groves already exist or are being newly planted." Bougainville District Annual Report; Annual Report-Bougainville District 1954/55, (part 4), Papua New Guinea Archives: 496/ARC6A917/BN7.

52 Christine Hotsia, recorded interview with author, Hanahan, Buka Island, Autonomous Region of Bougainville, 3 October 2006. Prohibition on swimming had ensured the ecosystem of the reef fish and shellfish (the abus - protein - that women had traditionally collected) was left undisturbed and could continually be replenished.

53 Land cannot be left fallow for as long and cropping periods are extended, while unfavourable land previously rejected is now used. Land shortage has also meant that firewood is harder to source. Women also 
As the passage from the Bougainville Annual Report makes clear, Buka women were also working alongside men in establishing cash crops. In 1948 copra trading on the island resumed again after the war, with villagers embarking on a significant extension of village plantings of coconut groves. ${ }^{54}$ Patrol officers complained that the peoples along the north east coast were being foolhardy in their enthusiasm for cash cropping (this despite the administration's encouragement), neglecting subsistence to take on cash cropping. ${ }^{55}$ These complaints suggest that from the very start of village cash cropping indigenous women (primarily responsible for subsistence) were quite extensively involved in copra production. Women also came to be involved in the marketing of introduced crops like peanuts and watermelon and other crops newly introduced by didimen. By the mid-1950s half of all stallholders at the main market in Buka town were women, and at the Karola market on the west coast of the island they made up the majority of those marketing (though Karola was traditionally a women's barter market rather than a market based on exchange for money). ${ }^{56}$

Though women often provided equal labour to that of men towards cash crop production, very rarely was the income derived from this shared equally with them. ${ }^{57}$ Indeed, the income that they made through marketing - and could hold on to - was relatively insignificant as an income source compared to that which could be generated through cash cropping. ${ }^{58}$ Women were not equal recipients of the money generated through development, and any income they did generate was spent primarily on family subsistence. Even when women began to engage and indeed play a significant role in commercial economic production this went unrecognised because women's involvement in income-generating work was less regular (though not necessarily less intensive), and because of the way in which women's income was spent (on family - food and other basic goods, clothing, school fees). As a result their labour was generally regarded as an extension of their subsistence work and understood as undertaken primarily in their role as mothers.

\footnotetext{
report that reef fish are no longer as plentiful as they once were (again larger numbers relying on the same resources). See R.M. Bourke and T. Betitis, Sustainability of Agriculture in Bougainville Province, Papua New Guinea, Canberra: Land Management Group, Department of Human Geography, 2002, pp.75-78.

54 Max Rimoldi and Eleanor Rimoldi, Hahalis and the Labor of Love: A Social Movement on Buka Island, Explorations in Anthropology, Oxford: Providence: Berg, 1992, pp. 77-78.

55 Patrol Report cited in Rimoldi and Rimoldi, Hahalis and the Labor of Love, p. 77.

56 Bougainville District Annual Report; Annual Report-Bougainville District 1958-59, p. 32. Papua New Guinea Archives: 496/ARC6A917/BN7.

57 Margaret Nakikus et al., Papua New Guinea: Women in Development Sector Review, Port Moresby: UNDP, 1991.

58 Ben R. Finney, New Guinea Entrepreneurs: Indigenous Cash Cropping, Capital Formation and Investment in the New Guinea Highlands, New Guinea Research Bulletin 27, Canberra: The Australian National University, New Guinea Research Unit, 1969.
} 


\section{The everyday work of Buka mothers: In the past, in present day Buka}

Buka women told me that traditionally - from taim bipo tru-mothers had been responsible for the basic subsistence of their family. Apart from the help received from men to clear land, they were responsible for all other work in the gardens. They prepared the ground, planted, weeded, harvested and carried back garden produce for the family. This was work women often performed together. ${ }^{59}$ Christine Hotsia remembered from her childhood, "There were no lazy women back then. Mothers worked hard in the garden. They worked together and would often work hard for two or three days, and then take a day off for rest." ${ }^{60}$ Others described their mothers as similarly disciplined,

$S$ : She [my mother] was always going for gardening, never missing a day. ${ }^{61}$

$N$ : My mother had six children. Every day she worked in the garden, and we would follow her. My mother was a very hard-working woman. ${ }^{62}$

Women collected firewood, carried water, did the laundry, prepared food and cared for children. For a time in the early 1960s followers of the Hahalis Welfare Society, recognising women had traditionally been unfairly loaded with too much of the work of subsistence, reversed gendered roles. Men-including tsunono (chiefs) - were forced to take on women's work and, as anthropologists Max and Eleanor Rimoldi explained it, "feel the pain the women had felt all those years." ${ }^{63}$ Women who had been a part of Welfare told me of this experiment:

$R$ : Before the men wouldn't help, they'd just sit in the village and it would be women doing the hard work of clearing the bush and planting the food. But now some of the good ones they helped women to feed the family. Everyone was happy in the village about this. My husbandhe was a good one, a real hard-working man. He'd gotten used to the collective work [of the Society] and he organised the young men to work together and help out, to help me. ${ }^{64}$

\footnotetext{
59 To clarify, women did not work their gardens together. Each woman was generally responsible for her own garden. But they would leave together, take breaks together, and occasionally holler out to one another as they worked. This is not a hard and fast rule since on occasion women would contribute/help with labour in each other's gardens.

60 Christine Hotsia, recorded interview with author, Hanahan, Buka Island, Autonomous Region of Bougainville, 3 October 2006. See also interviews with Rose Willy, 5 November 2006, Hahalis; and Martha Tonang, 7 November 2006, Lemankoa.

61 Saline Girana, recorded interview with author, Hahalis, Buka Island, Autonomous Region of Bougainville, 4 March 2007.

62 Namosi Tousalia, recorded interview with author, Hanahan, Buka Island, Autonomous Region of Bougainville, 17 October 2006.

63 Rimoldi and Rimoldi, Hahalis and the Labor of Love, p. 148.

64 Rose Tehoei, recorded interview with author, Hahalis, Buka Island, Autonomous Region of Bougainville, 31 December 2006.
} 


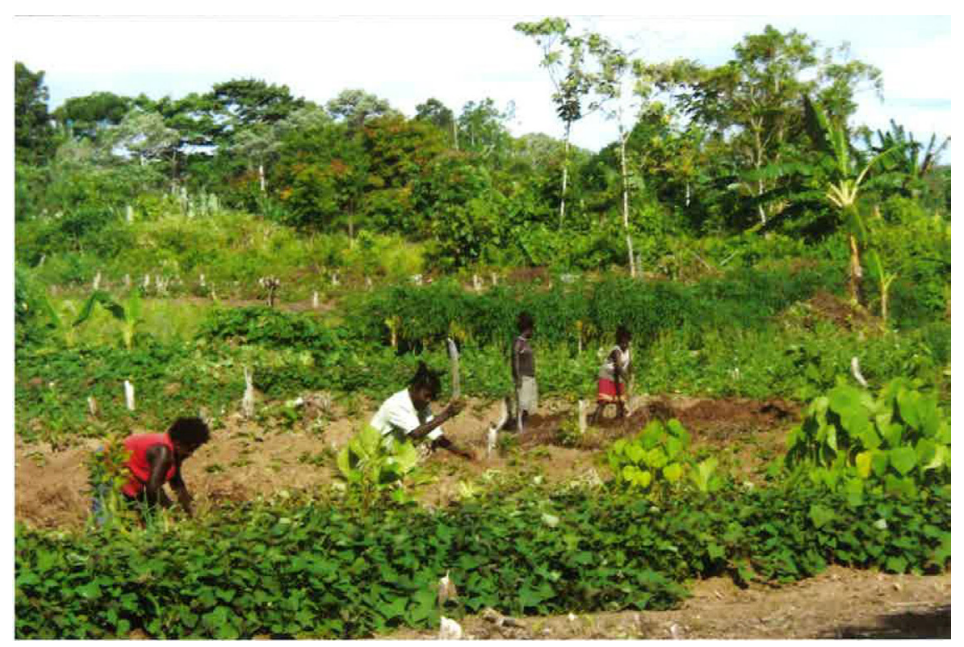

Figure 15. Women working together in the garden. Hahalis, Buka, Autonomous Region of Bougainville 2006

Source: Photograph by Jemima Mowbray.

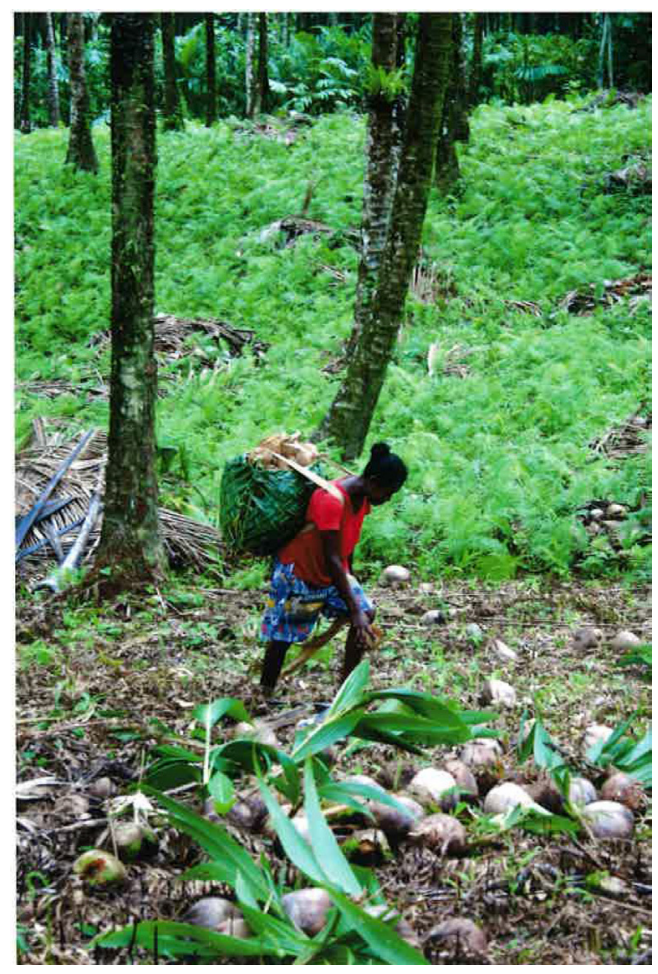

Figure 16. "Working copra" for cash. Carrying coconuts to be broken then smoked. Hahalis, Buka, Autonomous Region of Bougainville 2006 


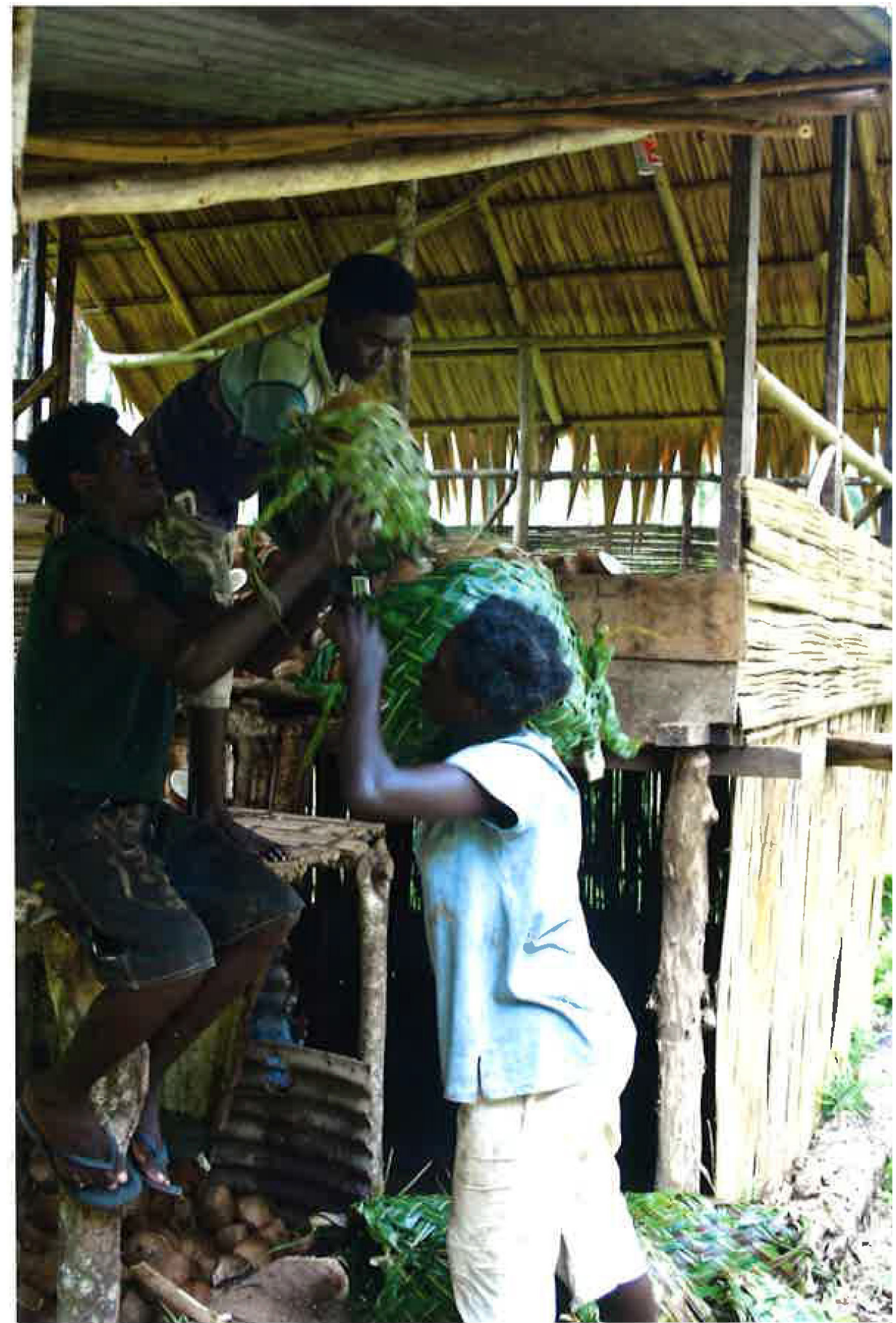

Figure 17. Handing over coconuts at the smukhaus (smoke house) built in the bush. Hahalis, Buka, Autonomous Region of Bougainville, 2006 
However women said the results of this "reversal" had not lasted very long after it was first initiated, and were not sure this had been particularly significant in the long term. ${ }^{65}$ Instead many of the women involved in the Welfare Society stressed their equal participation in the wok bung - or collective labourinvolved in establishing and managing the Society's cash crops,

$R$ : We worked together with the men [during this time]. We'd clean the coconut plantations - all of us, men and women together. The men would shake down the coconuts and then together we'd collect them and take them to the [copra] driers. And everyone, men and women, worked in the garden. The men would clear the area and the women would dig holes to plant the taro, but the men would help with this. The men would do the heavy work, but those women that could they'd work with the men. ${ }^{66}$

$C$ : And all the women used to work with the men during this time. The men would clear the bush and the women would get the hoes and plant ... we would get money through these projects. ${ }^{67}$

It was also a mother's responsibility to pass on appropriate knowledge about custom, to both young boys and girls - although of course there was much knowledge and practice that was gender specific. ${ }^{68}$ For young girls this meant training them with gardening skills. Most women remembered that as young children they had from very early on followed their mothers to the gardens,

65 Ibid.; Cecilia Beseke, recorded interview with author, Hahalis, Buka Island, Autonomous Region of Bougainville, 17 February 2007.

66 Rose Tehoei, recorded interview with author, Hahalis, Buka Island, Autonomous Region of Bougainville, 31 December 2006.

67 Cecilia Beseke, recorded interview with author, Hahalis, Buka Island, Autonomous Region of Bougainville, 17 February 2007.

68 So Josephine Tsiperi could talk about aspects of custom as being only appropriate to be shared between females or between men:

In terms of learning kastom - we, us girls, we would get it from women. Boys would get taught by men. I mean sometimes they would do it with the whole clan - they would sit down, meet, and when they were having these meetings, discussions - they would touch on kastom during this time. Men must know about these things. Women must know about these. But in terms of kastom this is the responsibility of mothers. (Josephine Tsiperi, recorded interview with author, Hanahan, Buka Island, Autonomous Region of Bougainville, 20 October 2006).

Jessie Marise explained that some stories (or knowledges) are shared only from mother to daughter. She told me of her mother introducing her to the lilihane (spirits of the ancestors) of her place. She took her down to the sea edge, to a certain spot where huge boulders mark the entrance to a passage of water that leads straight out through the reef. This is where her clan's lilihane-described as small snakes, though some are huge, and big enough to fight with dogs - reside. The stories and knowledge she learnt from her grandmother she shared with her daughter. "They are not anyone else's stories. They belong to me, and my mother and my grandmother before her." Jessie Marise, recorded interview with author, Elutupan, Buka Island, Autonomous Region of Bougainville, 21 February 2007. 
and when old enough they planted their own small plots. Agnes Gohul, born in 1937, remembered the small tasks her mother and other women would ask her to help with:

Back then I was little and I couldn't hold the big digging stick and dig the deep holes needed for planting the taro. So I would go and help the women with little tasks like weeding, or carrying rubbish and heaping it together. I would help them. I would carry my own little woksak [a woven basket] back. They would teach me how to weave these, and how to carry them back to the village [loaded with produce]. ${ }^{69}$

Josephine Tsiperi, born some thirty-years later, described also planting her own small garden. The produce from this was not only for family consumption, but served also as goods for sale at market:

I told you my mother was a woman who would plant things to sell in order to get money. Well I followed her in this. I learnt this from her. So me too, I would follow whatever my mother was doing, whatever little things she was planting. I'd go to the market and sell things until I was big enough to go to school and then I stopped doing this. ${ }^{70}$

In this way young girls learnt not only the skills associated with gardening, but also those to do with marketing - what to grow, how to bundle it, and how much to sell it for.

This shift from simple subsistence to gardening for both family and for the market that emerges when these two testimonies are placed side by side, points to the expansion in mothers' responsibilities taking place through this period. A mother's work encompassed providing the basics of subsistence for her family, but what constituted "basics" increasingly included goods that could only be purchased with cash. ${ }^{71}$ A "good mother" was now required to generate income to cover the costs of those things now needed by her family in the everyday - clothes, food, kerosene, transport money, and so on. Though their husbands, if waged, were ostensibly expected to contribute towards subsistence costs, very often their incomes were (and women report this as a continuing

69 Agnes Gohul, recorded interview with author, Lemanmanu, Buka Island, Autonomous Region of Bougainville 29 October 2006.

70 Josephine Tsiperi (from Lonahan), recorded interview with author, Hanahan, Buka Island, Autonomous Region of Bougainville, 20 October 2006

71 As Josephine Tsiperi had described, in the case of her mother:

My mother used to work garden and sell produce [from it] to get money. Another way was to work copra. But most of it - the money my mother collected to pay my school fees - she got it from planting gardens. Because she found it very hard to work copra by herself. But copra she did work it a little, but mostly she planted things - all different kinds of things that she would then get money for to help out. For school fees, for clothing. (Josephine Tsiperi, recorded interview with author, Hanahan, Buka Island, Autonomous Region of Bougainville, 20 October 2006). 
issue) spent on alcohol or other luxury goods. From women's oral testimonies it became clear that they felt that the heaviest burden was that of school fees. Though fathers were certainly obliged to provide monies towards this, it was generally mothers who came up with the cash (through additional labour done specifically towards generating monies for these). And it was mothers who were blamed when monies could not be found.

From the 1950s onwards Buka women as mothers engaged in cash-cropping and in "making projects" (marketing agricultural crops) to earn a small income. They often did this intermittently - as and when they needed the monies. The income they earned was then distributed straight back into the subsistence costs of their families. Because this work was not consistently done (as in waged labour), and money was not (and could not be) be accumulated, this workthough income-generating - was regarded and valued simply as an extension or subsidy of women's basic subsistence work in the garden. It was mother's work, work for the household, and as such was seen by colonial officers and even, to an extent, villagers as reproductive labour rather than recognised as economically productive work.

There are two key practical implications of the classification of women's work in this way. First women often do not get given an equal share of income derived from cash cropping, despite their equal contribution of labour. Women I talked to in the village often saw waged work (government work, or waged work in town) as preferable because then they would "get what they worked for." Martha Macintyre, in interviews undertaken with women working in the mining industry in PNG, found that many women felt wages they received were more likely to be directly under their control and also that they would have more personal discretion about how these were spent. ${ }^{72}$ They identified their wages in opposition to money made by growing marketable goods or working on cash crops with the help of family members on family land. Buka women saw this same distinction, a wage - as opposed to money made through work in the gardens growing market goods or on cash crops grown on family landseemed a more independent source of income. Second, because women are less likely to be envisaged as primary income earners they have historically been marginalised from educational and training opportunities, trapped in a selfperpetuating cycle of exclusion from waged labour.

Women are keenly aware of their continuing marginalisation in this regard. When I interviewed Buka women, the questions I asked about waged work invariably were answered with a reference to education: an expression of gratitude

72 Martha Macintyre, "Money changes everything: Papua New Guinean women in the modern economy," in Managing Modernity in the Western Pacific, ed. Mary Patterson and Martha Macintyre, St Lucia: University of Queensland Press, 2011, pp. 90-120, p. 104. 
(to parents, to teachers) that they received the education required to get a job, or alternatively their regret at having missed out on an education and thus a whole range of opportunities. Education was seen as key to waged work, or at least the main way in which women could articulate their aspirations in relation to this. This came from their very clear understanding that waged employment relied on acquiring an education beyond primary school. ${ }^{73}$ Many Buka women explained their differential access to secondary education and further vocational training as having excluded them from "the good life," or at least a better life.

\section{Buka women, waged work and education}

Most women when asked about whether their parents had sent girls to school, said they felt that there had been just as many girls as boys at their primary school and that parents were generally keen to see all children get an education; they "valued education." They told me girls continuing on through to high school and to further training was a different matter altogether.

Yet, though available statistics for the district suggest that the enrolment of girls in Bougainville was slightly higher than that at the broader national level, girls have nonetheless been at a clear disadvantage in terms of access to education in the region (see Table 1). ${ }^{74}$ In 1950 females constituted less than a third of primary enrolments in the Bougainville district; this had improved to around 45 per cent of enrolments by the 1960s. It was, however, in postprimary schooling that the disparity was clearest: at the secondary level female enrolments fluctuated slightly but never rose above 28 per cent of enrolments in the period up until 1970.

Girls in Buka faced a number of barriers to accessing education. Schools were often a long way from village settlements. Describing Hanahan Primary School in the early 1950s, Christine Hotsia, who was born just before the war, explained:

At this school there were boys and girls, all these children who had to come from Tohatsi through to Hahalis. They used to all come here to

\footnotetext{
73 Romeo Tohiana has described the appreciation of education by Buka villagers as key to early mission recruitment of adherents who wanted to gain basic literacy and potentially jobs with the administration and mission, and thus material wealth. Tohiana, "The Hahalis Welfare Society of Buka, North Solomons Province," p. 37.

74 No figures were available for this period for Buka Island alone. Helen Geissinger, writing in the late 1990s, noted that girls from the islands had traditionally been at a slight advantage in terms of access to education because generally within island cultures (Bougainville, New Ireland, East New Britain and Manus) women have held higher status within their own societies relative to their mainland counterparts. Girls in Bougainville had historically had the highest level of enrolment among the provinces. See Helen Geissinger, "Girls' access to education in a developing country," International Review of Education 43(5/6) (1997): 423-38, p. 429.
} 
this one school. No, no ... it was from Gogohe through to Sing. Those from Gogohe would sleep here at the station.... And from Hahalis and Tohatsi they would come every morning and then go back to the village. So there were houses for boys on this side, and houses for girls on this other side close to the cliff, near the sisters. On Fridays they [students from distant villages] would all go back and then come back again on Mondays. ${ }^{75}$

Table 1. Percentage of male to female enrolments in schools (both administration and mission), 1950-1970

\begin{tabular}{|c|c|c|c|c|c|c|c|c|c|c|}
\hline \multirow[b]{3}{*}{ Year } & \multicolumn{4}{|c|}{ Bougainville District } & \multicolumn{6}{|c|}{ Papua and New Guinea } \\
\hline & \multicolumn{2}{|c|}{ Primary } & \multicolumn{2}{|c|}{$\begin{array}{c}\text { Intermediate } \\
\text { /Secondary }\end{array}$} & \multicolumn{2}{|c|}{ Primary } & \multicolumn{2}{|c|}{$\begin{array}{c}\text { Intermediate } \\
\text { /Secondary }\end{array}$} & \multicolumn{2}{|c|}{$\begin{array}{l}\text { Vocational } \\
\text { /Technical }\end{array}$} \\
\hline & M & $\mathbf{F}$ & M & $\mathbf{F}$ & M & $\mathbf{F}$ & M & $\mathbf{F}$ & M & $\mathbf{F}$ \\
\hline 1950 & $69 \%$ & $31 \%$ & $73.5 \%$ & $26.5 \%$ & ${ }^{*} 63.5 \%$ & $36.5 \%$ & ${ }^{*} \ldots$ & ${ }^{*} \ldots$ & ${ }^{*} \ldots$ & ${ }^{*} \ldots$ \\
\hline 1961 & $55 \%$ & $45 \%$ & $76 \%$ & $24 \%$ & $61 \%$ & $39 \%$ & $82 \%$ & $18 \%$ & $93 \%$ & $7 \%$ \\
\hline 1965 & $54 \%$ & $46 \%$ & $77.5 \%$ & $22.5 \%$ & $61 \%$ & $39 \%$ & $79 \%$ & $21 \%$ & $92 \%$ & $8 \%$ \\
\hline 1970 & $54 \%$ & $46 \%$ & $72 \%$ & $28 \%$ & $63 \%$ & $37 \%$ & $72 \%$ & $28 \%$ & $76.5 \%$ & $23.5 \%$ \\
\hline
\end{tabular}

Source: Figures based on statistical information published in Department of Territories, Report to the General Assembly of the United Nations on the administration of the Territory of New Guinea 1950/51, Administration of the Territory of New Guinea, Canberra: Commonwealth Government Printer, p. 160; Papua New Guinea Department of Education Statistics Section, Comparative Staffing and Enrolments Statistics: Papua New Guinea Education System, 1960-1972, PNG Dept of Education, Konedobu, Papua New Guinea, 1973, pp. 3-36.

Many young students slept in simple houses under the supervision of the mission staff, and would have to bring food supplies for the week when they returned to school on Monday morning. The long distances children were required to travel meant girls were less likely to be enrolled. Girls were required to help their mothers in the gardens to provide subsistence for their families. If a girl had to travel away for schooling, the loss of her labour impacted heavily on the family (and particularly her mother's workload). Additionally the distance girls were required to travel from villages to school raised fears for their safety, both in terms of the threat of physical assault as well as the threat of sorcery.

When parents did not have enough money to send all their children, they prioritised their sons' education over their daughters. This was a calculated decision: educated sons held a higher value to their parents than did their daughters. Jessie Marise, born in 1947, described how her family had been very poor while she was growing up. Her father had died when she was young and her mother had no siblings to turn to. Her mother struggled to find money to send her and her brother to school each year. "To earn a little money we would

75 Christine Hotsia, recorded interview with author, Hanahan, Buka Island, Autonomous Region of Bougainville, 3 October 2006. 
sell kerosene. My mother used to do this-borrow money from one man and then buy a full drum of kerosene and we would sell it on in the village. And that is how she paid our small fees. But it was hard." 76

Jessie had loved school and having done well in her studies planned to continue on to high school. Her brother told her, however, that the family would not have enough money to send both of them through high school. Jessie had been accepted into the government-run high school at Hutjena and the school fees required were significantly higher than those at the mission-run primary school they had been attending. "My brother was in Grade 5 and I had just heard that I had gotten in to Hutjena and he said to me, 'Jessie, you can't go to school.' And I said, 'why not?' 'No-one can pay your fees. You must get married!'”77 Though she had been intent on continuing her education Jessie understood she did not have much choice.

Okay, I said to him, but brother if I have children, then who will help me when they are ready to go to school, who will pay their school fees? And he made a promise to me then, he said, "I promise I will help you. I want you to marry because we are struggling for money." So I said yes. ${ }^{78}$

For the next few years Jessie and her new husband, a teacher earning a regular wage, supported her brother through high school and continued to support him when he went on to university. Her brother became a Chief Magistrate within the Papua New Guinean courts and has fulfilled his promise, paying the school fees for all nine of her children. "This was his promise. He tells my children, if not for me your mother would have been working too, but because of me-I ruined it for her. But I say, no-you didn't ruin it for me. You were thinking of the future. We couldn't both go to school at the same time." ${ }^{\prime 79}$

Patricia Johnson, writing in the early 1990s, argued that girls' traditional (and continued) disadvantage in accessing education in PNG had been a key factor in the increasing disparity between men's and women's, and especially rural women's, access to wealth and political power (measured by Johnson in terms of access to political office).$^{80}$ For families and individuals it was access to income that was considered perhaps the most valuable or desired outcome of a Western education. As Johnson explained, "While the government may phrase education policy in terms of national development and human resources,

\footnotetext{
76 Jessie Marise, recorded interview with author, Elutupan, Buka Island, Autonomous Region of Bougainville, 21 February 2007.

77 Ibid.

78 Ibid.

79 Ibid.

80 Patricia Lyons Johnson, “Education and the 'new' inequality in Papua New Guinea," Anthropology and Education Quarterly, 24(3) (1993): 183-204.
} 
the parents who are responsible for sending their children to school are more immediately concerned with the impact of education on their children's future occupations and, thereby, on their incomes." ${ }^{81}$

Education was something highly valued by all the women I spoke to, especially by those who had not been able to continue their education or not been able to access it in the first place. The positive relationship between educational achievement and income was clear to the Buka women I interviewed: "I think back on what I did [leaving school] and I get cross with myself. Because I ruined my chances, didn't I?" ${ }^{\prime 2}$ Young women who did not go on to high school, or dropped out before graduating generally came back to the village and got married. They took on the work of mothers in the village-basic subsistence labour, caring for children, caring for older relatives. Namosi Tousala, born in 1960, described what it was like for those who dropped out. "They'd finish and then they'd just stay in the village doing nothing really (stap nating long ples). When girls they finished Grade 6 and 'drop out,' then they only have one choice-they work garden, that's all." ${ }^{13}$

Educational achievement was thus considered crucial for women to access employment and a regular and reliable income, and thereby a measure of independence. Older women who attended school when it was, as they described it "just the A-B-Cs" (though in Buka they often called them the 'a-e-i-u's), ${ }^{84}$ said that by the time they were mothers, things in the village had changed and they had hoped that their children would go further with education so that they might get a job. ${ }^{85}$ For those women of the younger generation (up to fifty years old) who had continued on to high school, the importance of "doing well" at high school was tied to their future goal of attaining waged employment. When asked what they had wanted to do after high school, though many had held a preference regarding vocation they also made clear that they were ultimately happy with any training that led to good paid employment. Rachel Topu, born in 1958, had dreamed of training to be a didimeri (a female agricultural extension officer), but the year she left school Vudal Agricultural College in East New Britain had closed off their intake. When she realised her parents would not allow her to travel as far as Popondetta or Mount Hagen (the locations of the other agricultural colleges) she knew she "had no choice." Instead she enrolled at Arawa Technical College in the south of Bougainville. "Did I always want to go

\footnotetext{
81 Ibid., p. 189.

82 Rita, recorded interview with author, Elutupan, Buka Island, Autonomous Region of Bougainville, 23 January 2007.

83 Namosi Tousala, recorded interview with author, Hanahan, Buka Island, Autonomous Region of Bougainville, 17 October 2006.

84 Older women over 65 referred to this, and generally dropped the " $\mathrm{o}$ " in the run of vowels. These were the first letters they learnt at mission school they told me.

85 Cecilia Beseke (born 1936), recorded interview with author, Hahalis, Buka Island, Autonomous Region of Bougainville, 17 February 2007.
} 
work in an office? No, not at all. My first choice was to become an agriculturalist ... it was okay though, I just wanted to get work." ${ }^{86}$ Cathleen Kopkop, born in 1966, and trained and employed as a teacher explained, "When I was in Grade 10, the big thing I was thinking about and looking forward to was would I get a good result, so that I would be able to go on and find good work or not?... I really wanted that I would be one of these financially employed women." ${ }^{\prime 87}$ Carmelita Toahei, born in 1965, similarly was concerned to find "good work." "My thoughts had been-I must get work, and get a salary. And if I can earn my own money, hold it in my hands, then I'll be able to do all those little things for my home and my village that I'd like to see happen." ${ }^{88}$

Carmelita's turn of phrase, "earn my own money, hold it in my hands," highlighted the importance she-and many women I spoke to-placed on earning their own wages so that they had a measure of control over money. ${ }^{89}$ Violence against women is a serious, pervasive problem in Bougainville, as it is throughout PNG. ${ }^{90}$ A number of the women I interviewed in Buka told me of violence they had been subject to within their marriages. Martha Macintyre, who has written extensively on gender violence in PNG, suggests that given the demonstrated failure of current awareness programs aimed at reducing violence, broader programs addressing the structural economic and social inequalities between women and men are needed, focusing on women's improved access to education, health and employment opportunities. ${ }^{91}$ Macintyre argues that the individual empowerment of women (for example via rights-based training)

86 Rachel Topu, recorded interview with author, Lemanmanu, Buka Island, Autonomous Region of Bougainville, 6 November 2006.

87 Cathleen Kopkop (from KetsKets), recorded interview with author, Hanahan, Buka Island, Autonomous Region of Bougainville, 20 October 2006.

88 Carmelita Toahei, recorded interview with author, Hanahan, Buka Island, Autonomous Region of Bougainville, 20 October 2006.

89 And see Macintyre, "Money changes everything," p. 104.

90 See Richard Eves for a discussion of the extent of the problem in contemporary Buka. Richard Eves, Exploring the Role of Men and Masculinities in Papua New Guinea in the 21st Century: How to address violence in ways that generate empowerment for both men and women, Report for Caritas Australia, 2006, pp. 21-23, online: http://www.baha.com.pg/downloads/Masculinity\%20and\%20Violence\%20in\%20PNG. pdf, accessed 16 March 2013. Eves here follows a shift within recent scholarship and advocacy that has seen the "domestic violence" of traditional advocacy and analytical focus usefully reconceptualised as gender violence. This framing is one that acknowledges the false binary of domestic/public violence - especially given the problematic "fit" of this distinction in the Pacific context - and expands analysis to talk about violence and abuse faced by children and in some instances men in Papua New Guinea. See Margaret Jolly, Christine Stewart with Carolyn Brewer (eds), Engendering Violence in Papua New Guinea, Canberra: ANU E Press, 2012 online: http://press.anu.edu.au?p=182671, accessed 13 May 2014. See also Martha Macintyre, "'Hear us, women of Papua New Guinea!': Melanesian women and human rights," in Human Rights and Gender Politics: Asia-Pacific Perspectives, ed. Anne-Marie Hilsdon et al., London and New York: Routledge, 2000, pp. 147-71; and Laura Zimmer Tamakoshi, “'Wild pigs and dog men': rape and domestic violence as 'women's issues' in Papua New Guinea," in Gender in Cross-Cultural Perspective, ed. Carolyn Brettell and Caroline Sargent, Englewood Cliffs, NJ: Prentice-Hall, 2005, pp. 538-53.

91 Martha Macintyre, "Gender violence in Melanesia and the problem of Millennium Development Goal No. 3," in Engendering Violence in Papua New Guinea, ed. Margaret Jolly, Christine Stewart with Carolyn Brewer, Canberra: ANU E Press, 2012, pp. 239-66, online: http://press.anu.edu.au?p=182671, 13 May 2014. 
without a simultaneous shift in social values and cultural norms can mean in the current context that women who stand up for their rights are seen as "disempowering men" and provoke violent retaliation. ${ }^{92}$ She argues strongly for the prioritising of projects that address women's material empowermentincluding policies of positive discrimination to increase the numbers of women attending school after primary school, and strategies to increase the number of women employed in the formal workforce and help reduce salary inequalities between men and women. ${ }^{93}$ This connects with the sentiments of most women I spoke to in Buka. For Buka women economic independence meant more than simply greater autonomy in terms of deciding what income could be spent on. It also meant women who earned their own money were freer to leave abusive relationships. ${ }^{94}$ It gave them more control over their lives.

\section{Conclusion}

After World War II the colonial administration decided that agricultural development and the transformation of village economies from agricultural subsistence to commercial production was key to the colonies' future. Indigenous men were to be the key economic agents in driving this transformation. Indigenous women, on the other hand, were marginalised from the training provided to men to enable commercial farming, and actively sidelined by policies that presumed men's rights over land and over any income generated from that land. Even when the administration began to reform labour legislation to encourage more indigenous women to work, women still found themselves marginalised from waged work because of their limited access to education (in real terms, and relative to men).

The work of women today remains primarily that of subsistence agriculture. The women of Halia and Haku are particularly aware that despite the value they place on their work in the gardens, it is generally devalued - both within the modern capitalist economy, and increasingly within customary/traditional economies as commodities have slowly crept in and replaced the traditional wealth which women played a primary role in producing. Cash payments are slowly, for example, replacing the taro grown and the pigs raised by women for use in cultural exchange and ritual. Women are proud of their work in their

92 Macintyre, "Gender violence in Melanesia and the problem of Millennium Development Goal No. 3," pp. 243-247.

93 Macintyre, "Gender violence in Melanesia and the problem of Millennium Development Goal No. 3," p. 256.

94 Again Martha Macintyre's interviews with women indicated that many understood a wage as providing economic independence and thus freedom from abusive relationships - either a route out of established violent relationships, or alternatively the freedom not to enter a relationship in the first place or only on their own terms. Macintyre, "Money changes everything," p. 103. 
garden, but recognise the many ways in which this locks them out of various other opportunities. Anne Dickson-Waiko has observed that Papua New Guinean women's early exclusion from mainstream colonial life - including their limited access to employment and educational opportunities - meant that "ultimately it was men who were trained to man the state apparatus at independence." ${ }^{\prime 95}$ Halia and Haku women express frustration with women's lack of political representation and acknowledge their limited capacity to engage in community and government activities because of the continued pressures of work for family (including substantial subsistence labour), but particularly emphasise exclusion in terms of employment and education as avenues of self-empowerment they believe promise greater control over their lives.

While much work has been done on the missions and the varying effects for indigenous women of the "cult of domesticity" in Papua New Guinea, the central role played by the state in reshaping domesticity through its policies of land and labour has been largely unrecognised and under-researched. Examination of the gendered effects of colonial policy and programs reveals a fundamental paradox: the work of women, work believed by the administration to be the source of indigenous women's "denigration" or "servitude," was intensified through its various policies and program, even those aimed specifically at addressing women's low status. These interventions occurred primarily via labour policy, but also through initiatives in the organisation of land, and indigenous methods of family planning. The negative consequences of colonial initiatives for women's everyday lives are shown in the lived experiences and changes as described by women in Buka. A recurring feature in their accounts, however, is the consistent rejection of and resistance to colonial adjudications that devalued women's labour, and dismissed their own views and values.

\section{Acknowledgements}

I wish to thank Anthea Vogl for her very helpful feedback and advice on earlier versions of this paper. I would like to gratefully acknowledge the work of Margaret Jolly and Hyaeweol Choi in organising the Paradoxes of Domesticity conference in August 2012, and subsequently bringing this volume together. Special thanks also to Margaret Jolly for her expert advice and suggestions for the paper. I am particularly grateful to the many Halia and Haku women of Buka who generously shared their days and insights with me for this research during my stay on the island.

95 Dickson-Waiko, “Women, individual human rights, community rights," p. 59. 
This text taken from Divine Domesticities: Christian paradoxes in Asia and the Pacific, edited by Hyaeweol Choi and Margaret Jolly, published 2014 by ANU Press, The Australian National University, Canberra, Australia. 